\title{
Winter Phytoplankton Composition Occurring in a Temporarily Ice-Covered Lake: a Case Study
}

\author{
Burak Öterler* \\ Trakya University, Faculty of Science, Department of Biology, Balkan Campus, 22030, Edirne, Turkey
}

Received: 16 March 2017

Accepted: 24 May 2017

\begin{abstract}
It is generally thought that the seasonal succession of phytoplankton is minimized during winter months. However, some studies have indicated that there is also diversity in phytoplankton communities in winter. The main purpose of this study was to determine the phytoplankton community structure and species composition of a lake during winter, when covered with ice. Phytoplankton samples from the lake were taken in the winter seasons of 2015 and 2016, during the period from the appearance of the ice cover on the lake until it completely melted, and phytoplankton composition in the lake and some physicochemical properties of the lake water were measured. The phytoplankton community was found to be dominated by Cyclotella meneghiniana, which is a centric diatom, followed by the flagellates, especially Synura uvella, small cryptophytes (Cryptomonas paramecium), dinoflagellates (Peridinium aciculiferum and Gymnodinium sp.), and nonfilamentous greens (Pediastrum duplex, Scenedesmus spp., and Monoraphidium spp.). Phytoplankton development under ice-cover is largely related to temperature, but the development of phytoplankton composition is random. A low correlation was determined between the dominant organisms and ice thickness. Species biodiversity was low, but the dominant species started to be represented with different taxonomic groups after mid-winter.
\end{abstract}

Keywords: ice cover, phytoplankton composition, winter limnology, shallow lake

\section{Introduction}

Since the term "growing season" is widely used to define summer months in mild ponds, winter months seem to be perceived as an inactive period. Freshwater scientists have assumed in some studies that biological activity in the pond icecap is insignificant or the primary producers engage in heterotrophism or dormancy because of ice, especially in high-latitude lakes with heavy snow [1]. In

*e-mail: burakoterler@trakya.edu.tr recent years, it has become more important to understand how physical and ecological conditions under ice affect lake ecology [2]. It is well known that high-altitude and high-latitude frozen lakes are usually considered when limnological studies in winter conditions are carried out. However, it is possible that lakes and rivers in temperate regions may be partially or completely iced over due to a decrease in temperature during prolonged winter conditions. It is widely known that during the long winter months in temperate regions, biological processes either stop or continue to work at low rates, and these periods are considered relatively less important than those involv- 
ing heightened biological processes. In the current situation, heating affects the surface water temperature directly and physicochemical and biological processes indirectly [3].

Temperature is one of the most important variables for lakes in the formation of ice cover, and many lakes and rivers in the northern hemisphere are directly affected by climate change [4-5]. Moreover, despite the direct climatic effects on lake ecosystems, seasonally ice-covered lentic ecosystems are severely understudied, particularly in comparison to the open water [6].

In addition to temperature, because of the short photoperiod and variable physical conditions during winter months, light can also be a limiting factor for photosynthesis under ice [7-8]. However, when the light is sufficient for photosynthesis, the environment under ice cover can be quite favourable; the complex under-ice environment's convection can sustain the nutrients and the algae mixed in the photic region [2].

Especially due to the timing and characteristics of precipitation, wind, temperature change, and solar radiation, ice cover may have more light transmittance than lake water during the winter season [9]. For example, in the case of Russia's Lake Baikal, ice cover provides a foothold and can generate a wide living space to make it easier for attached algae to access the light [10]. However, compared to other seasons, aquatic organisms in lake ecosystems during the ice-cover period may struggle with problems like light usage, gas exchange between the atmosphere and water, and mixing detention due to wind and low temperatures [11]. Therefore, organisms under ice may migrate upwards to survive - especially to benefit from light until the melting period [12].

Icing mounds in big lakes are mobile, and they are especially likely to move with the wind [13]; however, during cold winters, those in medium-sized lakes are static, while they can be mobile during relatively mild winters [9]. The winter ice-cover in small lakes is stable [11]. Temperature during cold and windless nights in small and shallow lakes can swiftly cool down to the point of freezing faster than it can in deep lakes, and melting can take a long time [14]. In such cases, we do not have enough information or estimation about how the community structure will be affected or how it will shape the new communities [15-16]. Ecological dynamics in aquatic ecosystems are especially vulnerable to climate change [17-19], as the thermal structure of a lake and its mixing pattern are directly and predominantly influenced by climate [20].

Despite these pressures, pelagic organisms may develop ecological adaptations, and the species variety and organism number may surprisingly increase under the ice cover; such organisms may be found in enormous numbers [21]. In fact, in a study done by Twiss et al. [22], it was found that in the middle of winter, when the lake was frozen, phytoplankton growth was almost as high as in the summer months. The same results were reported by Lenard and Wojciechowska, Wojciechowska and Lenard, Babanazarova et al., Özkundakci et al., and Kalinowska and Grabowska [23-27]. The main objectives of the present study, which was carried out in a eutrophic, temperate, artificial, and shallow Balkan Lake, were: i) to determine the spatial and temporal distribution of phytoplankton in the lake by identifying its community structure during ice-covered periods and ii) to determine the response of the phytoplankton community to some environmental variables during extreme winter conditions.

\section{Material and Methods}

\section{Study Site}

The Balkan Arboretum was constituted in Trakya University in 1996; in 1998, Balkan Lake was artificially created by partially arranging and deepening a wetland and raising the front with an embankment. The lake is classified as a shallow eutrophic pond [28-29]. The lake is only 39 meters above sea level and covers an area of $0.8 \mathrm{~km}^{2}$; it has a maximum depth of $180 \mathrm{~cm}$ and an average Secchi depth of $72 \mathrm{~cm}$. It is located southeast of suburban Edirne $\left(41^{\circ} 40^{\prime} 41^{\prime \prime} \mathrm{N}, 26^{\circ} 33^{\prime} 49^{\prime \prime} \mathrm{E}\right)$. The climate is typical-

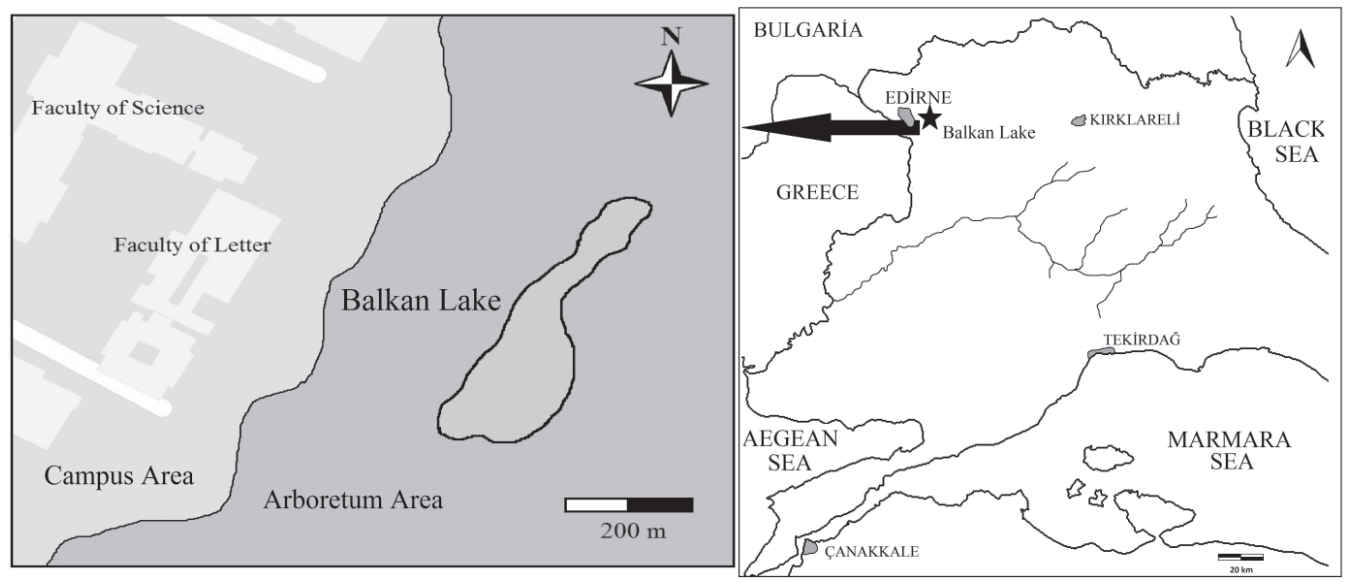

Figure 1. Map of Balkan Lake and its location in Trakya University Campus area. 
Table 1. Weekly distributions of the environmental variables measured.

\begin{tabular}{|c|c|c|c|c|c|c|c|c|c|c|c|c|}
\hline & Air Temp. & Wat. Temp. & Ice & PAR & $\mathbf{p H}$ & Cond. & DO & TDS & SRP & NO $_{2}$ & NO $_{3}$ & $\mathbf{S O}_{4}$ \\
\hline Week 1 & 2 & 2.2 & $\mathbf{0 . 4}$ & 0 & 8.05 & 0.94 & 3.55 & 0.61 & 2.71 & 0.005 & 4.4 & 70 \\
\hline Week 2 & -3 & 1.6 & 2.4 & 111.9 & $\mathbf{8 . 2 5}$ & 0.98 & 4.15 & 0.57 & 1.66 & 0.005 & 3.9 & $\mathbf{7 8}$ \\
\hline Week 3 & -7 & 0.8 & 4.8 & 91.2 & 7.82 & 0.96 & 3.15 & 0.56 & 2.55 & 0.006 & $\mathbf{4 . 8}$ & 38 \\
\hline Week 4 & -5 & 1.2 & 3.1 & 110.2 & 7.88 & 0.94 & 3.25 & 0.51 & 1.61 & $\mathbf{0 . 0 0 7}$ & 4.5 & 44 \\
\hline Week 5 & -4 & 1.8 & 4.4 & 91.1 & 7.63 & 0.92 & 2.9 & 0.5 & 2.27 & $\mathbf{0 . 0 0 4}$ & 4.1 & 36 \\
\hline Week 6 & $\mathbf{- 8}$ & $\mathbf{0 . 3}$ & 5.4 & 100.2 & 7.86 & $\mathbf{0 . 8 7}$ & $\mathbf{2 . 2 5}$ & $\mathbf{0 . 4 9}$ & 2.65 & $\mathbf{0 . 0 0 4}$ & 4.4 & $\mathbf{1 5}$ \\
\hline Week 7 & -5 & 0.6 & $\mathbf{1 0 . 4}$ & $\mathbf{4 3 . 3}$ & $\mathbf{7 . 1 2}$ & 0.88 & 2.35 & $\mathbf{0 . 4 9}$ & $\mathbf{2 . 7 5}$ & 0.006 & 4.2 & 22 \\
\hline Week 8 & -3 & 1.8 & 7.1 & 67.3 & 7.23 & 0.94 & 2.25 & 0.5 & 1.88 & 0.005 & $\mathbf{3 . 8}$ & 35 \\
\hline Week 9 & 2 & 2.1 & 7.8 & 53.1 & 7.66 & $\mathbf{0 . 9 9}$ & 3.35 & 0.57 & 1.65 & $\mathbf{0 . 0 0 7}$ & 4.5 & 33 \\
\hline Week 10 & 6 & 2.5 & 2.7 & 126.7 & 7.54 & 0.92 & 3.15 & 0.57 & $\mathbf{1 . 4 2}$ & 0.005 & 4.4 & 52 \\
\hline Week 11 & -1 & 1.6 & 1.4 & $\mathbf{1 3 2 . 2}$ & 7.35 & 0.97 & 3.45 & 0.57 & 2.35 & 0.005 & 4.1 & 65 \\
\hline Week 12 & $\mathbf{9}$ & $\mathbf{3 . 2}$ & 0 & 0 & 7.89 & 0.97 & $\mathbf{4 . 7 5}$ & $\mathbf{0 . 6 3}$ & 1.75 & 0.005 & 4.2 & 75 \\
\hline
\end{tabular}

*Air Temp. (air temperature, ${ }^{\circ} \mathrm{C}$ ), Wat. Temp. (water temperature, ${ }^{\circ} \mathrm{C}$ ), PAR (photosynthetically active radiation, $\mu \mathrm{mol} \mathrm{m}^{-2} \cdot \mathrm{s}^{-1}$ ) Ice (ice thickness, $\mathrm{cm}$ ), Cond. (conductivity, $\mu \mathrm{S} . \mathrm{cm}^{-1}$ ), DO (dissolved oxygen, mg. $\mathrm{L}^{-1}$ ), TDS (total dissolved solids, g.L.-1), $\mathrm{SRP}$ (soluable reactive phosporus, g.L $\mathrm{L}^{-1}$ ), $\mathrm{NO}_{2}$ (nitrite, $\mathrm{mg} . \mathrm{L}^{-1}$ ), $\mathrm{NO}_{3}$ (nitrate, $\mathrm{mg} . \mathrm{L}^{-1}$ ), $\mathrm{SO}_{4}$ (sulphate, $\mathrm{mg} . \mathrm{L}^{-1}$ )

ly characterised by four distinct seasons; the mean annual air temperature in this region is about $13.7^{\circ} \mathrm{C}$, and the long-term annual precipitation is approximately $50.12 \mathrm{~kg} / \mathrm{m}^{2} / \mathrm{yr}^{-1}$ [30]. The coldest months are December, January, and February, with mean monthly temperatures ranging from 2.7 to $4.6^{\circ} \mathrm{C}$. The lake regularly freezes over during winter months; ice-covered periods vary from a few days to several tens of days, plus one or two times of intermittent ice-cover in a year. We defined the winter and ice-covered period based on the winter solstice, starting on 4 December 2015 and ending on 19 February 2016 (Fig. 1).

\section{Sampling and Identification}

Winter severity varied substantially over the study period; ice cover started to appear on 4 December 2015 and melted on 19 February 2016. There was partial ice cover in the last two weeks of our 12-week study. Additional seasonal samplings were carried out in autumn 2015, spring 2016, summer 2016, and autumn 2016 for comparison with the winter period.

Sampling of phytoplankton during the ice-covered periods was performed weekly. Following the weather temperature drop to under zero values, the first sample was taken by crushing the ice cover at midday. Light transmission (photosynthetically active radiation, PAR) during sampling was measured with a lux meter. Ice thickness was measured at different parts of the sampling sites with the help of a calliper. Sampling lasted 12 weeks until the ice cover on the lake completely melted. Detailed descriptions of sampling techniques and sample processing are given by Driescher et al. and Gerten and Adrian [31-32].
Water temperature, $\mathrm{pH}$, dissolved oxygen (DO), total dissolved solids (TDS), and conductivity were measured on-site during samplings using field-type equipment. A simple dark bottle ( $2 \mathrm{~L}$ ) was used to obtain water samples just below the ice of the water body to determine nitrate $\left(\mathrm{NO}_{3}\right)$, nitrite $\left(\mathrm{NO}_{2}\right)$, soluble reactive phosphorus (SRP), and sulphate $\left(\mathrm{SO}_{4}\right)$ - all of which were measured in the laboratory in accordance with APHA methods (Eaton et al. 2012). Chlorophyll- $a$ was determined by spectrophotometric analysis following Nusch [33].

Sampled phytoplankton specimens were identified via the investigation of temporary preparations. For this purpose, water samples were filtered from Whatman GF/A paper with the help of a water trompe and dissolved in

Table 2. Phytoplanktonic abundance determined seasonally in Balkan Lake and their distributions with respect to groups (cell. $\mathrm{ml}^{-1}$ ).

\begin{tabular}{|c|c|c|c|c|}
\hline & Winter & Autumn & Summer & Spring \\
\hline Bacillariophyta & 125,047 & 41,244 & 141,315 & 83,682 \\
\hline Chlorophyta & 71,396 & 95,843 & 134,807 & 69,568 \\
\hline Cyanophyta & 3,425 & 106,215 & 184,672 & 9,724 \\
\hline Charophyta & 726 & 58,214 & 56,834 & 24,188 \\
\hline Cryptophyta & 30,302 & 1,442 & 0 & 52,044 \\
\hline Miozoa & 17,538 & 1,247 & 9,322 & 10,322 \\
\hline Ochrophyta & 53,339 & 614 & 1,050 & 88,677 \\
\hline Euglenophyta & 86,755 & 88,144 & 88,433 & 79,854 \\
\hline Average & 388,527 & 392,963 & 616,433 & 418,059 \\
\hline
\end{tabular}


Table 3. List of phytoplanktonic algal composition of Balkan Lake during the study period.

\begin{tabular}{|c|c|c|c|c|c|c|c|c|c|c|c|c|}
\hline \multirow{2}{*}{ Algological Groups } & \multicolumn{12}{|c|}{ Sampling Periods (Weeks) } \\
\hline & 1 & 2 & 3 & 4 & 5 & 6 & 7 & 8 & 9 & 10 & 11 & 12 \\
\hline \multicolumn{13}{|l|}{ BACILLARIOPHYTA } \\
\hline \multicolumn{13}{|l|}{ Class: Bacillariophyceae } \\
\hline \multicolumn{13}{|l|}{ Order: Bacillariales } \\
\hline Nitzschia acicularis Smith & + & + & + & + & + & + & + & + & & & & + \\
\hline Nitzschia hungarica Grun. & & & & + & & & & & & & & \\
\hline Nitzschia palea (Kütz.) Smith & + & + & + & + & + & & + & & + & & + & \\
\hline \multicolumn{13}{|l|}{ Order: Cocconeidales } \\
\hline Cocconeis placentula Ehren. & & & & & + & + & & & & & & \\
\hline \multicolumn{13}{|l|}{ Order: Cymbellales } \\
\hline Cymbella lanceolata (Agardh) Agardh & & + & + & & & & + & & + & & & \\
\hline Cymbella tumida (Bréb.) Van Heurck & + & + & + & & + & + & & + & + & + & & + \\
\hline Gomphonema clavatum Ehren. & & & & & & + & & & + & & & \\
\hline Gomphonema parvulum (Kütz.) Kütz & & + & + & & + & + & + & & & & + & \\
\hline Gomphonema truncatum Ehren. & & & + & + & + & & & + & & & + & + \\
\hline \multicolumn{13}{|l|}{ Order: Fragilariales } \\
\hline Fragilaria crotonensis Kitton & + & + & + & & & & + & & & + & & \\
\hline Fragilaria ulna (Nitzs.) L-Bertalot & + & + & + & + & + & + & & + & + & + & & + \\
\hline \multicolumn{13}{|l|}{ Order: Naviculales } \\
\hline Craticula cuspidata (Kütz.) Mann & & & & & & + & & & & & & \\
\hline Navicula cryptocephala Kütz. & + & + & + & + & & + & + & & + & + & + & + \\
\hline Navicula lanceolata (Ag.) Kütz. & & + & + & + & & + & + & & & & & \\
\hline Navicula sp. & + & + & + & + & & + & + & + & + & + & + & + \\
\hline Pinnularia dactylus Ehren. & & & + & + & & + & & & & + & & + \\
\hline \multicolumn{13}{|l|}{ Order: Rhopalodiales } \\
\hline Epithemia adnata (Kütz.) Bréb. & + & + & + & + & + & & + & + & + & + & + & + \\
\hline Rhopalodia gibba (Ehren.) Müller & & + & & + & + & + & & + & & & & \\
\hline \multicolumn{13}{|l|}{ Order: Surirellales } \\
\hline Cymatopleura solea (Bréb.) Smith & & & & & & + & & & & & & \\
\hline \multicolumn{13}{|l|}{ Order: Tabellariales } \\
\hline Diatoma vulgaris Bory & + & + & & & & & & & & & + & + \\
\hline \multicolumn{13}{|l|}{ Order: Thalassiophysales } \\
\hline Amphora ovalis (Kütz.) Kütz. & + & + & & & & & & & & & + & + \\
\hline \multicolumn{13}{|l|}{ Class: Coscinodiscophyceae } \\
\hline \multicolumn{13}{|l|}{ Order: Aulacoseirales } \\
\hline Aulacoseira granulata (Ehren.) Simon. & + & & & & & & & & + & & & \\
\hline \multicolumn{13}{|l|}{ Order: Melosirales } \\
\hline Melosira varians Agardh & + & & & & & & & & & & & + \\
\hline \multicolumn{13}{|l|}{ Class: Mediophyceae } \\
\hline Order: Stephanodiscales & & & & & & & & & & & & \\
\hline
\end{tabular}


Table 3. Continued.

\begin{tabular}{|c|c|c|c|c|c|c|c|c|c|c|c|c|}
\hline Cyclotella delicatula Hustedt & + & + & + & + & + & & + & + & + & + & + & + \\
\hline Cyclotella meneghiniana Kütz. & + & + & + & + & + & + & + & + & + & + & + & + \\
\hline Stephanodiscus hantzschii Grun. & + & + & + & + & + & & + & + & & + & + & + \\
\hline \multicolumn{13}{|l|}{ CHLOROPHYTA } \\
\hline \multicolumn{13}{|l|}{ Class: Chlorophyceae } \\
\hline \multicolumn{13}{|l|}{ Order: Chlamydomonadales } \\
\hline Chlamydomonas reinhardtii Dang. & & + & + & + & + & + & + & + & + & + & & + \\
\hline \multicolumn{13}{|l|}{ Order: Sphaeropleales } \\
\hline Monoraphidium arcuatum (Kors.)Hindák & + & + & + & + & & & + & + & + & + & + & \\
\hline Monoraphidium contortum (Thuret) Kom. & + & + & + & + & & + & + & + & + & + & + & + \\
\hline Monoraphidium griffithii (Berk.) Kom. & + & + & + & + & + & & + & + & + & & + & \\
\hline \multicolumn{13}{|l|}{ Order: Volvocaceae } \\
\hline Pandorina morum (Müller) Bory & + & & & & + & & & & & & + & \\
\hline \multicolumn{13}{|l|}{ Order: Sphaeropleales } \\
\hline Pediastrum duplex Müller & + & + & + & + & + & + & + & + & + & + & & + \\
\hline Scenedesmus acuminatus (Lag.) Chodt. & + & + & + & + & + & & + & + & + & + & + & + \\
\hline Scenedesmus magnus Meyen & + & & + & + & + & + & + & + & + & & + & \\
\hline Scenedesmus opoliensis Richter & + & & + & + & & + & + & + & + & + & + & + \\
\hline Scenedesmus quadricauda (Turp.) Bréb. & + & + & + & + & + & & + & + & + & + & + & + \\
\hline Scenedesmus sempervirens Chod. & & + & + & & & & + & + & & & + & \\
\hline Tetraëdron minimum (Braun) Hansg. & + & + & + & & & & + & + & & + & & \\
\hline \multicolumn{13}{|l|}{ Class: Trebouxiophyceae } \\
\hline \multicolumn{13}{|l|}{ Order: Chlorellales } \\
\hline Chlorella pyrenoidosa Chick & + & + & + & + & + & & + & + & + & + & + & + \\
\hline Oocystis parva West & & & & & & + & & & & & & \\
\hline \multicolumn{13}{|l|}{ CYANOPHYTA } \\
\hline \multicolumn{13}{|l|}{ Class: Cyanophyceae } \\
\hline \multicolumn{13}{|l|}{ Order: Nostocales } \\
\hline Aphanizomenon gracile Lemm. & + & & & + & & & + & & & & + & \\
\hline \multicolumn{13}{|l|}{ Order: Oscillatoriales } \\
\hline Komvophoron crassum (Vozz.)Anag.\&Kom. & & & & & & + & & & & & & \\
\hline Oscillatoria formosa Bory & + & & & & & & & + & & & + & \\
\hline Oscillatoria limnetica Lemm. & & + & & + & & & + & & & + & + & + \\
\hline \multicolumn{13}{|l|}{ Order: Synechococcales } \\
\hline Pseudanabaena sp. & & + & & & & & & & + & + & & + \\
\hline \multicolumn{13}{|l|}{ CHAROPHYTA } \\
\hline \multicolumn{13}{|l|}{ Class: Conjugatophyceae } \\
\hline \multicolumn{13}{|l|}{ Order: Desmidiales } \\
\hline Closterium littorale Gay & & + & & & & & & & & & & + \\
\hline Closterium lunula Ehren. & & & & & & & & & & & & + \\
\hline Cosmarium botrytis Meneg. & & + & & & & & & & & & & \\
\hline
\end{tabular}


Table 3. Continued.

\begin{tabular}{|c|c|c|c|c|c|c|c|c|c|c|c|c|}
\hline Cosmarium depressum (Näg.) Lundell & + & & & & & & & + & & & & + \\
\hline \multicolumn{13}{|l|}{ CRYPTOPHYTA } \\
\hline \multicolumn{13}{|l|}{ Class: Cryptophyceae } \\
\hline \multicolumn{13}{|l|}{ Order: Cryptomonadales } \\
\hline Cryptomonas ovata Ehren. & + & + & + & + & + & + & + & + & + & + & + & + \\
\hline Cryptomonas paramaecium Ehren. & & & + & + & & & + & + & + & + & + & + \\
\hline \multicolumn{13}{|l|}{ MIOZOA } \\
\hline \multicolumn{13}{|l|}{ Class: Dinophyceae } \\
\hline \multicolumn{13}{|l|}{ Order: Gymnodiniales } \\
\hline Gymnodinium caudatum Prescott & & + & & + & + & + & + & + & + & + & + & + \\
\hline Gymnodinium fuscum (Ehrenberg) Stein & & & + & & + & & + & + & + & + & + & + \\
\hline \multicolumn{13}{|l|}{ Order: Peridiniales } \\
\hline Peridinium gatunense Nygaard & & & & & + & + & + & & & & & + \\
\hline \multicolumn{13}{|l|}{ OCHROPHYTA } \\
\hline \multicolumn{13}{|l|}{ Class: Synurophyceae } \\
\hline \multicolumn{13}{|l|}{ Order: Synurales } \\
\hline Synura sp. & + & + & + & + & + & & + & + & + & + & + & + \\
\hline Synura uvella Ehren. & + & + & + & + & + & + & + & + & + & + & + & + \\
\hline \multicolumn{13}{|l|}{ EUGLENOPHYTA } \\
\hline \multicolumn{13}{|l|}{ Class: Euglenophyceae } \\
\hline \multicolumn{13}{|l|}{ Order: Euglenales } \\
\hline Euglena acus (Müller) Ehren. & + & & + & + & + & + & & + & + & + & + & + \\
\hline Euglena gracilis Klebs & + & + & + & + & + & & + & + & + & + & + & + \\
\hline Euglena limnophila Lemm. & + & & + & & & + & + & & + & + & + & + \\
\hline Euglena polymorpha Dang. & & + & + & & & + & + & + & + & + & + & + \\
\hline Euglena sp. & & + & & + & + & & + & & & & & \\
\hline Lepocinclis sp. & + & & + & + & & & & & + & + & + & + \\
\hline Monomorphina pyrum (Ehren.) Meresch. & & & + & & + & + & & + & & + & & \\
\hline Phacus longicauda (Ehren.) Duj. & & & & & + & & & & & & & \\
\hline Phacus pleuronectes (Müller) Duj. & & & & & & + & & & & & & \\
\hline Strombomonas sp. & & + & + & + & & & & + & & + & & + \\
\hline Trachelomonas hispida (Perty) Stein & & + & + & + & + & + & + & + & + & + & + & + \\
\hline Trachelomonas volvocina (Ehre.) Ehren. & + & + & + & + & + & + & + & + & + & + & + & + \\
\hline
\end{tabular}

$10 \%$ glycerine. A Uthermöhl counting chamber was used to calculate the organism number per litre. The numbers, shapes, and sizes of the organisms were used as the basis for the calculation of biomass for phytoplankton [3435]. Algae species were identified with an Olympus microscope. For the identification of diatoms, frustules were cleaned with concentrated $\mathrm{HCl}$ and $\mathrm{H}_{2} \mathrm{SO}_{4}$. Identifications were carried out at $1000 \times$ magnification under immersion oil, and identification of taxa was conducted with the help of related literature [36-42]. All identified species were checked in AlgaeBase [43].

\section{Statistical Analysis}

Abiotic variables were correlated with the main phytoplankton attributes using nonparametric Spearman correlation coefficients. Differences in all variables were tested using a nonparametric Kruskal-Wallis (KW) 
analysis of variance (ANOVA) median test. Differences at the $p<0.05$ level were accepted as significant. In addition, to compare sampling weeks, nonparametric statistics (the Mann-Whitney U test) were used. The existence of temporal and spatial differences of species diversity, richness, and evenness of the phytoplankton under icecover was determined by ANOVA [44]. Multivariate analyses were used to identify the environmental parameters that were most strongly associated with each other and to define associations between environmental factors and phytoplankton species. A canonical correspondence analysis (CCA) was performed using the XLSTAT-ADA statistical package to determine the relative importance of environmental variables, sampling time, and phytoplankton species [45].

\section{Results}

\section{Ice-Cover Period and Environmental Variables}

During the 12-week study the lake had ice cover for 77 days total. The average temperature was measured as $-1.5^{\circ} \mathrm{C}$. (During every sampling week, the average air temperature measurement was taken in the morning, midday, and evening.) Moreover, climatic conditions were defined as above-seasonal normal, cold, and relatively dry. The lake was covered with ice at night because the night-time temperature was below $0^{\circ} \mathrm{C}$ with wind and frost, although the temperature increased during daytime. Water temperature under the ice cover was determined as $1.6^{\circ} \mathrm{C}$ on average; the average ice thickness varied between the two winter seasons from $0 \mathrm{~cm}$ to $10.4 \mathrm{~cm}$. During the study, the highest measured PAR value was $132.2 \mu \mathrm{mol} \mathrm{m} \mathrm{m}^{-2} . \mathrm{s}^{-1}$ at the 11 th week, and the lowest value was measured as $43.3 \mu \mathrm{mol} \mathrm{m} \mathrm{m}^{-2} \cdot \mathrm{s}^{-1}$ at the 7 th week when there was ice cover. The measured physicochemical parameters from the study are given in Table 1.

\section{Phytoplankton Community Structure under Ice-covered Period Succession}

Phytoplanktonic species numbers determined during the winter months were not very different from those in the autumn and spring months. However, seasonal differences were determined in the phytoplanktonic group numbers (Table 2).

A total of 68 phytoplankton taxa in eight groups were determined during the winter period (Table 3). Among these taxa, rare species that made up less than $2 \%$ of the biovolume were grouped together under the category 'others' (Fig. 2). The average phytoplankton biovolumes ranged from $1.78 \mathrm{mg} . \mathrm{L}^{-1}$ to $11.67 \mathrm{mg} . \mathrm{L}^{-1}$, while the aver-

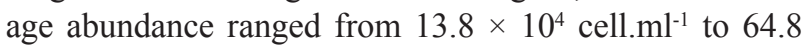
$\times 10^{4}$ cell. $\mathrm{ml}^{-1}$ throughout the study period. Species richness was in the range of 32-42, the Shannon-Wiener diversity index was 0.325-1.403, and Pielou's evenness was $0.083-0.361$ (Fig. 3). No significant relationship was found between ice thickness and phytoplankton biomass

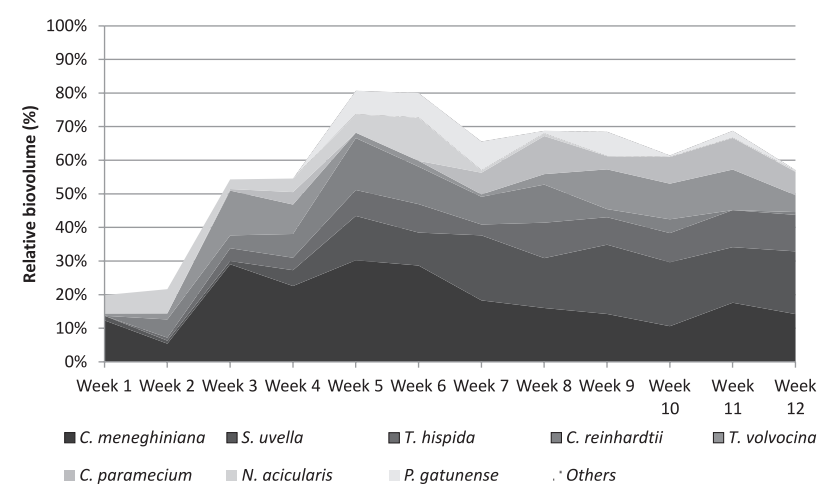

Fig. 2. Dominant species in ice cover and weekly distribution of their relative biovolumes.

( $R=0.109, p<0.05)$, cell count $(R=0.091, p<0.05)$, or species richness $(R=-0.131, p<0.05)$. However, while water temperature showed a positive correlation with $\mathrm{DO}(R=0.67, p<0.05)$, TDS $(R=0.73, p<0.05)$, and $\mathrm{SO}_{4}$ $(R=0.68, p<0.05)$, ice thickness showed negative correlations with temperature $(R=-0.66, p<0.05)$ and SRP $(R$ $=-0.67, p<0.05)$. Ice thickness was negatively correlated with dissolved oxygen $(R=-0.78, p<0.01), \mathrm{SO}_{4}(R=0.74$, $p<0.05)$, and chlorophyll- $a(R=0.83, p<0.01)$. None of the parameters measured in the lake indicated any correlation with PAR. Substantial correlations with Synura uvella and Trachelomonas hispida and chlorophyll- $a(R=0.93$, $p<0.05$ and $R=0.88, p<0.05$, respectively) were found. A negative correlation was found between Chlamydomonas reinhardtii and TDS $(R=-0.77, p<0.05)$, conductivity $(R=-0.64, p<0.05)$ and $\mathrm{pH}(R=-0.66, p<0.05)$; however, for ice thickness there was a positive correlation only with Scenedesmus quadricauda. The dominant organisms in the winter months were found to have a low correlation with ice thickness.

The winter phytoplankton community under ice in Balkan Lake was mainly dominated by Cyclotella meneghiniana and S. uvella. These species are among the dominant organisms in the lake all year round. With the formation of the ice cover, $C$. meneghiniana entered the

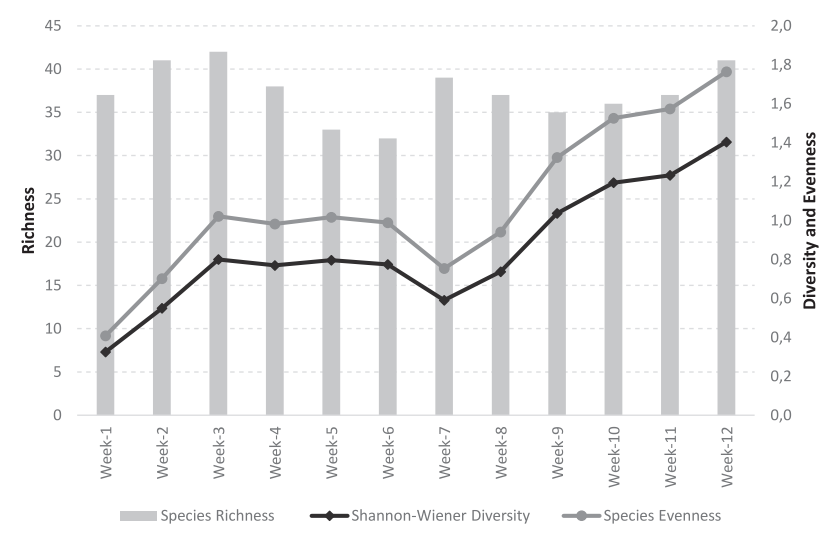

Fig. 3. Species richness (S), Shannon and Weaver diversity index $\left(\mathrm{H}^{\prime}\right)$, and evenness index of under-ice-cover algae species. 


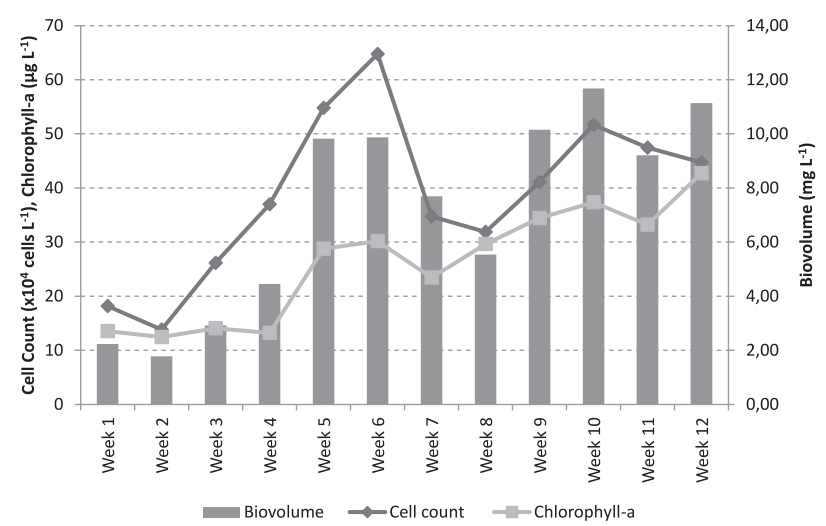

Fig. 4. Abundance, biovolume, and chlorphyll- $a$ values determined during study in Balkan Lake.

stability period and started to increase its number by midDecember, which in turn increased its biovolume, and the species became the most abundant organism in the lake. At the beginning of January, in the samples taken after the snowfall, $S$. uvella began to increase in number and became the dominant organism both in terms of species number and biovolume. The increase of $S$. uvella continued until February, making it one of the dominant organisms in spring.

Euglenoid species like Euglena, Lepocinclis, Phacus, and Trachelomonas are dominant organisms in the lake, especially during summer and autumn months; they were also represented in high numbers under the ice cover with T. hispida and Trachelomonas volvocina. The Chlorophyta members Scenedesmus and Pediastrum species are also among the dominant species in summer and autumn. During the study, C. reinhardtii, which is a filamentous, unicellular green alga within this group, was observed in the lake from early to mid-January during the snowy period. Among small chrysophytes, Cryptomonas spp. were determined to be represented in increased numbers due to their relatively smaller sizes; however, their biovolumes were lower than those of dinoflagellates. In the middle of January, Cryptomonas paramecium started to increase in number in the lake. Like $C$. paramecium, Peridinium gatunense also became apparent in the lake plankton at the end of the ice-cover. However, although they are dominant organisms in the lake during the summer and autumn months, blue-green algae were represented in low numbers, with relatively few species during the winter period. Abundance, biovolume, and chlorophyll-a values determined during the study period are given in Fig. 4.

\section{Canonical Correspondence Analysis}

CCA analysis was used to determine the relative abundance of lake phytoplankton and environmental factors. Fourteen taxa that were dominant in the phytoplankton community or exhibited an extreme increase in some weeks are shown in Fig. 5, along with their relationships with 10 different environmental factors. In the CCA biplot analysis, the eigenvalues of the first two axes were calculated as 0.63 and 0.39 , respectively. The first axis of CCA explained $13.06 \%$ of the total variance in species, while the second

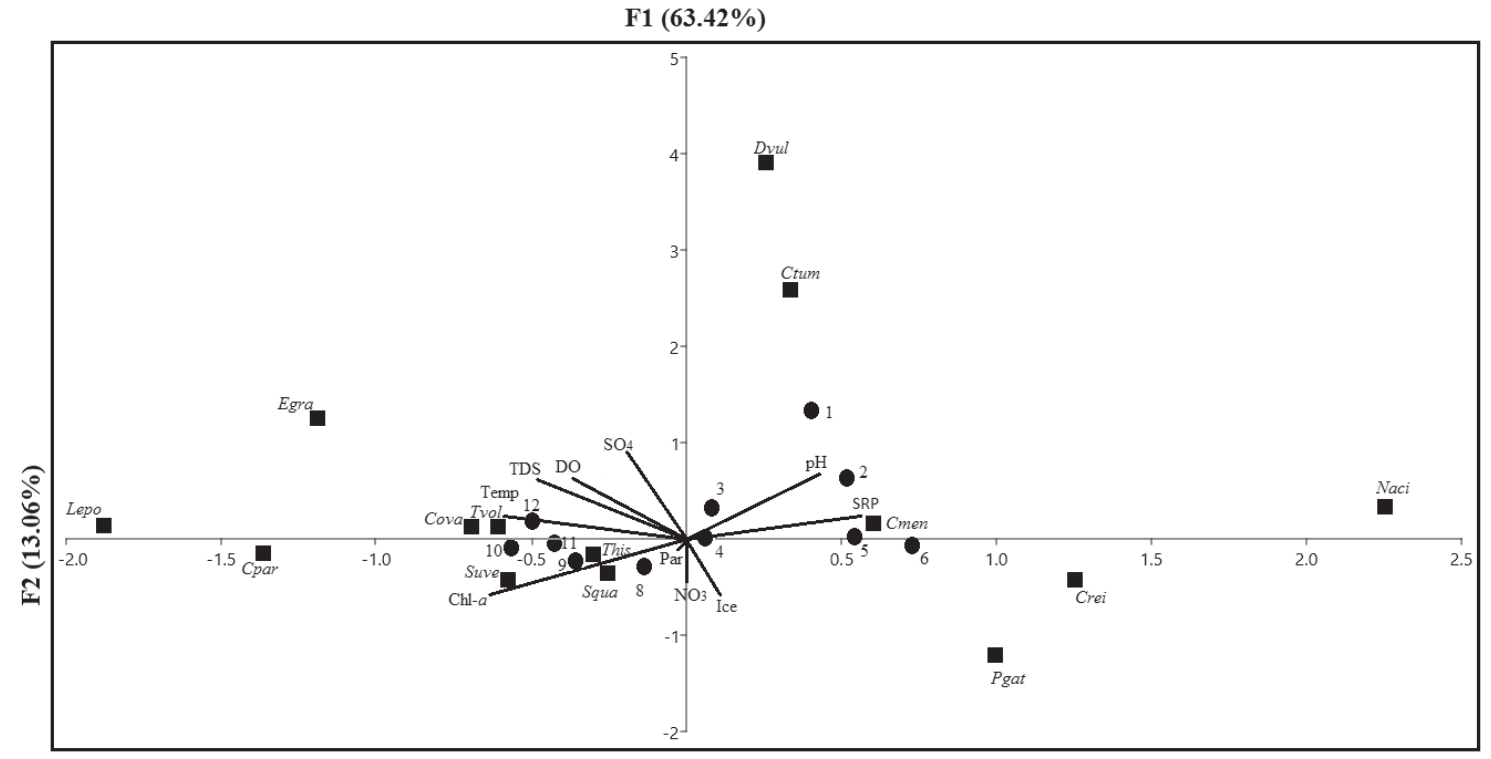

Fig. 5. Canonical correspondence analysis (CCA) results showing the sampling months, environmental variables, and 14 dominant taxa in Balkan Lake in the winter period. Environmental variables 0150 PAR: photosynthetically active radiation, DO: dissolved oxygen, $\mathrm{NO}_{3}$ : nitrate, SRP: soluble reactive phosporus, sulphate: $\mathrm{SO}_{4}$, Con: conductivity, TDS: totally dissolved solids, Temp.: water temperature, Chl-a: chlorophyll- $a$. Phytoplanktonic algal species, Cmen: Cyclotella meneghiniana, Ctum: Cymbella tumida, Dvul: Diatoma vulgaris, Naci: Nitzschia acicularis, Squa: Scenedesmus quadricauda, Crei: Chlamydomonas reinhardtii, Cova: Cryptomonas ovata, Cpar: Cryptomonas paramecium, Pgat: Peridinium gatunense, Suve: Synura uvella, Egra: Euglena gracilis, Lepo: Lepocinclis sp., This: Trachelomonas hispida, and Tvol: Trachelomonas volvocina. 
axis explained $63.42 \%$ of the total variance. Especially in weeks 8-11, chlorophyll- $a$ and $S$. uvella were correlated, and in weeks 8-9, T. hispida and S. quadricauda are correlated. C. meneghiniana was most highly related to SRP and least to $\mathrm{pH}$ in the first weeks of the study, while water temperature was correlated with $T$. volvocina and Cryptomonas species until the end of the study. There was no clear relationship between winter severity, ice thickness, and PAR.

\section{Discussion}

Ice cover in Balkan Lake remained continuous for several weeks during the winter months due to night temperature values below zero, leading to freezing of the upper water column, although the daytime temperature shows a relative increasing pattern toward midday of above zero values. During winter months, as the lakes are ice-covered and atmospheric entry is blocked, DO is only affected by photosynthesis and respiration [46]. Interpretation of DO data can be complicated by lateral transport and vertical mixing [47-48]. During the icecovered period, the oxygen concentration is extremely important for nutrient dynamics, the food web, and general functions of the ecosystem. Therefore, during this study, since oxygen entry from the atmosphere was prevented, DO values were determined to be extremely low. These values showed that the water of the lake could be defined as YSKYY criteria class III water, as the measured values were only due to photosynthesis and respiration [49]. As the ice-cover ended, the oxygen level increased; this was probably due to diffusion from the atmosphere. DO is one of the most significant limnological parameters for monitoring the exchange of water quality and aquatic life [50-51]. According to the EC directives put in place by the European Commission to protect the health of freshwater fish, the DO level in water must be over $4 \mathrm{mg} / \mathrm{L}$ for cyprinid species and over $6 \mathrm{mg} . \mathrm{L}^{-1}$ for salmonid species. Nitrite levels in water must be under $0.03 \mathrm{mg} . \mathrm{L}^{-1}$ for cyprinid species and under $0.01 \mathrm{mg} . \mathrm{L}^{-1}$ for salmonid species [52]. In the present study, DO and nitrite levels in lake water were recorded as $1.23 \mathrm{mg} . \mathrm{L}^{-1}$, $18 \mathrm{mg} . \mathrm{L}^{-1}, 0.189 \mathrm{mg} . \mathrm{L}^{-1}$, and $3.220 \mathrm{mg} . \mathrm{L}^{-1}$, which means that no nektonic organism could live in these extreme conditions. In another study carried out on water resources in the Balkan Arboretum, where the lake is located, high nitrite and nutrient levels were determined; these high levels were related to agricultural activities around the arboretum [53].

C. meneghiniana, which is a planktonic, centric diatom, was dominant in the phytoplankton succession of the lake during the ice-cover period until mid-January. After snowfall, $S$. uvella became the dominant organism of the lake under ice-cover, and it retained this dominance after the ice cover melted, especially during spring months. During the first half of the ice-cover period, $C$. reinhardtii and diatoms (mainly due to macrophytes submerged at the bottom, namely Ceratophyllum-dependent epiphytic diatoms) were dominant, especially in the beginning of the ice-cover period in the pond. After the second period of ice-cover, Trachelomonas species, P. gatunense, and C. paramecium were identified in high numbers and biovolume values in the lake.

The winter months - when the water temperature is close to $0^{\circ} \mathrm{C}$ - are not suitable for phytoplankton growth, but these organisms still adapt to winter conditions [23]. When the water temperature below the ice is $0^{\circ} \mathrm{C}$, centric diatom species like Cyclotella are known to grow well [54]. In addition, the interaction between light and nutrient availability is known to affect the distribution of Cyclotella spp. [55]. In a study carried out in Lake Erie during the winter months, a centric diatom, Aulacoseira islandica, was determined to be dominant, and another centric diatom, Cyclotella spp., was determined to be subdominant [56]. Similar results were found by Kiili et al., who reported high numbers of Cryptomonas sp. C. paramecium and Cryptomonas ovata among the subdominant organisms in Balkan Lake during the ice-cover period [57].

In extreme winter conditions, phytoplankton are dominated by small nanoplanktonic, heterotrophic, or mixotrophic species. These organisms are generally motile algae, such as dinophytes, cryptophytes, chrysophytes, or flagellate chlorophytes [58]. Despite convective mixing, smallcell flagellate species can maintain their position in the water column or move to places with better light conditions. This means that they can concentrate in large numbers in the upper water layer just below the ice cover [23, 57-58]. The dominant species we determined in our study mostly consisted of motile species, a finding that confirms the results of several previous studies $[3,23,27,25,46$, 57-58].

The dominant organisms of Balkan Lake from the second half of the winter period to spring months were $C$. meneghiniana and $S$. uvella. In particular, S. uvella was the dominant organism of the lake after snowfall, with its increased biovolume and chlorophyll- $a$ values. $S$. uvella is highly correlated with chlorophyll- $a$, and especially after the ice-cover melted, it could be considered one of the main chlorophyll- $a$ resources among phytoplanktonic organisms in the lake. The dominance of $S$. uvella has also been recorded by many previous researchers [25-27, 57].

According to the CCA analysis, there is a relationship between water quality parameters and temporal changes in dominant algae under ice cover. Considering the CCA results, it can be concluded that there is a substantial relationship between $S$. uvella and chlorophyll- $a$. Another dominant organism of the lake, C. meneghiniana, is found to be substantially correlated with SRP in the first weeks of the ice-cover period, and this is thought to influence the colonization of this species. This is because Cyclotella spp. growth is known to be specifically arranged according to the balance between light, nitrogen, and phosphorus [59]. Özkundakçı et al. found in their study that there is a positive correlation between ice thickness and $S$. uvella, Chlamydomonas spp., and Cryptomonas spp., but in our study no such correlation was determined. This difference 
can be attributed to the different ecologies and structures of the lakes studied [26]. The results of our CCA also revealed that there was no clear relationship between winter severity, ice thickness, and PAR.

\section{Conclusions}

The shallow, small Balkan Lake is covered with ice that decreases during winter months. Although phytoplankton growth under the ice cover is substantially related to temperature, the phytoplankton composition development is random. The dominant species composition in the lake before the ice cover continues until mid-winter and is replaced by motile, flagellated unicellular, and colonial species. These motile species create a spring bloom due to the effects of increased temperature, melting of the ice cover, and high nutrient concentrations. This event is thought to be affected by the absence of solar radiation and mechanical mixture under ice cover. The phytoplankton bloom and physicochemical structure formed by this event affect the trophic status of the lake in summer months.

\section{Acknowledgements}

I am grateful to Meriç Albay and Belgin Elipek for discussions that greatly improved this work. The author would like to thank to Volkan Aksoy for revising the English text and two anonymous reviewers for their fruitful comments.

\section{References}

1. LEPPÄRANTA M. Freezing of Lakes. Freezing of Lakes and the Evolution of their Ice Cover. Springer: Berlin Heidelberg, Germany, 301, 2015.

2. HAMPTON S.E., AARON W., GALLOWAY E., POWERS S.M., OZERSKY T., WOO K.H., BATT R.D., LABOU S.G., O'REILLY C.M., SHARMA S., LOTTIG N.R., STANLEY E.H., NORTH R.L., STOCKWELL J.D., ADRIAN R., Ecology under lake ice. Ecology Letters, 20 (1), 98, 2017.

3. DOKULIL M.T., HERZIG A., SOMOGYI B., VÖRÖS L., DONABAUM K., MAY L., NÕGES T. Winter conditions in six European shallow lakes: a comparative synopsis. Estonian Journal of Ecology, 63, 111, 2014.

4. LIVINGSTONE D.M., ADRIAN R. Modeling the duration of intermittent ice cover on a lake for climate-change studies. Limnology and Oceanography, 54, 1709, 2009.

5. MAGNUSON J.J., ROBERTSON D.M., BENSON B.J., WYNNE R.H., LIVINGSTONE D.M., ARAI T., ASSEL R.A., BARRY R.G., CARD V., KUUSISTO E., GRANIN N.G., PROWSE T.D., STEWART K.M., VUGLINSKI V.S. Historical trends in lake and river ice cover in the Northern Hemisphere. Science, 289 (1). 1743, 2000.

6. SOMMER U., ADRIAN R., DOMIS L.D.S., ELSER J.J., GAEDKE U., IBELINGS B., JEPPESEN E., LÜRLING M., MOLINERO J.C., MOOIJ, W.M., Van DONK E, WINDER M. Beyond the plankton ecology group (PEG) model: mechanisms driving plankton succession. Annual
Review of Ecology, Evolution, and Systematics, 43, 429, 2012.

7. TANABE Y., KUDOH S., IMURA S., FUKUCHI M. Phytoplankton blooms under dim and cold conditions in freshwater lakes of East Antarctica. Polar Biology, 31, 199, 2008.

8. BRUESEWITZ D.A., CAREY C.C., RICHARDSON D.C., WEATHERS K.C. Under-ice thermal stratification dynamics of a large, deep lake revealed by high-frequency data. Limnology and Oceanography, 60, 347, 2015.

9. LEPPÄRANTA M. Modelling of formation and decay of lake ice. In: George $G$ (ed) The impact of climate change on European lakes, vol 4, $1^{\text {st }}$ edn, Aquatic Ecology Series. Springer, Dordrecht, 63, 2010.

10. BONDARENKO N.A., BELYKH O.I., GOLOBOKOVA L.P., ARTEMYEVA O.V., LOGACHEVA N.F., TIKHONOVA I.V. LIPKO I.A., KOSTORNOVA T.Y., PARFENOVA V.V., KHODZHER T.V., AHN T.S., ZO Y.G. Stratified distribution of nutrients and extremophile biota within freshwater ice covering the surface of Lake Baikal. Journal of Microbiology, 50, 8, 2012.

11. KIRILLIN G., LEPPÄRANTA M., TERZHEVIK A., GRANIN N., BERNHARDT J., ENGELHARDT C., EFREMOVA T., GOLOSOVS., PALSHIN N., SHERSTYANKIN P., ZDOROVENNOVA G., ZDOROVENNOV R. Physics of seasonally ice covered lakes: a review. Aquatic Sciences, 74, 659, 2012.

12. FORSSTROM L., SORVARI S., RAUTIO M., SONNIINEN E., KORHOLA A. Changes in physical and chemical limnology and plankton during the spring melt period in a Subarctic Lake. International Review of Hydrobiology, 30, $1,2007$.

13. WANG K., LEPPÄRANTA M., REINART A. Modeling ice dynamics in Lake Peipsi. Internationale Vereinigung fur theoretische und angewandte, Limnologie, 29, 1443, 2006.

14. BENGTSSON L., HERSCHY R.W., FAIRBRIDGE R.W. Chapter 76, Ice covered lakes; Encyclopedia of lakes and reservoirs. Springer, Verlag, 863, 2012.

15. HOOPER D.U., ADAIR E.D., CARDINALE B.J., BYRNES, J.E.K., HUNGATE B.A., MATULICH K.L., GONZALEZ A., DUFFY J.E., GAMFELDT L., O'CONNOR M.I. A global synthesis reveals biodiversity loss as a major driver of ecosystem change. Nature, 486, 105, 2012.

16. O'CONNOR M.I., SELIG E.R., PINSKY M.L., ALTERMATT F. Toward a conceptual synthesis for climate change responses. Global Ecology and Biogeography, 21, 693, 2012

17. HAMPTON S.E., MOORE M.V., OZERSKY T., STANLEY E.H., POLASHENSKI C.M., GALLOWAY A.W.E. Heating up a cold subject: prospects for under-ice plankton research in lakes. Journal of Plankton Research, 37, 277, 2015.

18. ADRIAN R., O'REILLY C.M., ZAGARESE H., BAINES S.B., HESSEN D.O., KELLER W., LIVINGSTONE D.M., SOMMARUGA R., STRAILE D., Van DONK E., WEYHENMEYER G.A., WINDER M. Lakes as sentinels of climate change. Limnology and Oceanography, 54, 2283, 2009.

19. WILLIAMSON C.E., SAROS J.E., VINCENT W.F., SMOL J.P. Lakes and reservoirs as sentinels, integrators, and regulators of climate change. Limnology and Oceanography, 54, 2273, 2009.

20. DeSTASIO B.T., GOLEMGESKI T., LIVINGSTON D.M. Temperature as a Driving Factor in Aquatic Ecosystems. In: Likens, G.E. Encyclopedia of Inland Waters, 690, Elsevier B.V., 2009. 
21. SCHRÖDER A. Density -and size- dependent winter mortality and growth of late Chaoborus flavicans larvae. Plos One 8, e 75839, 2013.

22. TWISS M.R., SMITH D.E., CAFFERTY E.M., CARRICK H.J. Phytoplankton growth dynamics in offshore Lake Erie during midwinter. Journal Great Lakes Research, 40, 449, 2014.

23. LENARD T., WOJCIECHOWSKA W. Effect of extremely severe winters on under-ice phytoplankton development in a mesotrophic lake (Eastern Poland). Oceanological and Hydrobiological Studies, 43 (2), 147, 2013.

24. WOJCIECHOWSKA W., LENARD T. Effect of extreme serve winter on under-ice phytoplankton development in a mesotrophic lake (Eastern Poland). Oceanological and Hydrobiological Studies, 43 (1), 147, 2014.

25. BABANAZAROVA O., SIDELEV S. SCHISCHELEVA S. The structure of winter phytoplankton in Lake Nero, Russia, a hypertrophic lake dominated by Planktothrix-like Cyanobacteria. Aquatic Biosystems, 9, 18, 2013.

26. ÖZKUNDAKCI D., GSELL A.S., HINTZE T., TAUSCHER H., ADRIAN R. Winter severity determines functional trait composition of phytoplankton in seasonally ice covered lakes. Global Change Biology, 22, 284, 2016.

27. KALINOWSKA K., GRABOWSKA M. Autotrophic and heterotrophic plankton under ice in a eutrophic temperate lake. Hydrobiologia, 777, 111, 2016.

28. TOKATLI C. Use of Statistical Methods in Water Quality Assesment: A Case Study of Balkan Arboretum Area in Trakya University (Edirne, Turkey). Journal of Appiled Biological Sciences, 7 (3), 79, 2013.

29. http://balkanarboretumu.trakya.edu.tr/pages/kurulus\#. WKBNhjuLTIU T.C. Trakya Üniversitesi Balkan Arboretumu Canlı Ağaç Müzesi. (in Turkish) (Accessed date 12 Feb 2017).

30. https://www.mgm.gov.tr/veridegerlendirme/il-ve-ilceleristatistik.aspx?m=EDIRNE (Accessed date 02 Feb 2017)

31. DRIESCHER E., BEHRENDT H., SCHELLENBERGER G., STELLMACHER R. Lake Müggelsee and ist envrionment natural conditions and anthropogenic impacts. Internationale Revue der gesamten Hydrobiologie und Hydrographie, 78, 327, 1992.

32. GERTEN D., ADRIAN R. Climate-driven changes in spring plankton dynamics and the sensitivity of shallow polymictic lakes to the North Atlantic Oscillation. Limnology and Oceanography, 45, 1058, 2000.

33. NUSCH E. Comparison of different methods for chlorophyll and phaeopigment determination. Archiv für HydrobiologieBeiheftErgebnisse der Limnologie, 14, 14, 1980.

34. HILLEBRAND H., DÜRSELEN C., KIRSCHTEL D., POLLINGHER U., ZOHARY T. Biovolume calculation for pelagic and benthic microalgae. Journal of Phycology, 35 (2), 403, 1999.

35. SUN J., LIU D. Geometric models for calculating cell biovolume and surface area for phytoplankton. Journal of Plankton Research, 25 (11), 1331, 2003.

36. PESTALOZZI H.G. Das phytoplankton des susswasser Teil: 8 E. Schweizerbart'sche Verlagsbuchhandlund (Nagele U. Obermiller), Stuttgart, 1, 1982.

37. PRESCOTT G.W. Algae of Western Great Lake Area. Fifth printing. WMC. Brown Comp. Pub. Dubaque, lowa, 977, 1973.

38. KOMAREK J., FOTT B. Die binnnengewässer. Band 26, Das phytoplankton des süßwassers. 7 Teil, 1. Hälfte, Chlorophyceae (Grünalgen), Ordnung: Chlorococcales. E. Schweizerbart'sche Verlagsbuchhandlung, Stuttgart, 1983.
39. KRAMMER K., LANGE-BERTALOTH. Bacillariophyceae. 1-4 Teil. Süsswasserflora von Mitteleuropa. H. Ettl, J. Gerloff, H. Heynig, and D. Mollenhauer (editors). FischerVerlag, Stuttgart, Germany, 1984-2004.

40. KOMAREK J., ANAGNOSTIDIS K. Cyanoprokariota. 2. Teil: Oscillatoriales. In: Büdel B, Gärtner G, Krienitz L, Schagerl M(eds) Süßwasserflora von Mitteleuropa. Elsevier, Heidelberg, 750, 2005.

41. HINDAK F. Colour Atlas of Cyanophytes. VEDA, Bratislava, 253, 2008.

42. KRISTIANSEN J., PREISIG H.R. Phylum Chrysophyta (Golden Algae). In: The freshwater algal flora of the British Isles. An identification guide to freshwater and terrestrial algae. Second edition. (John, D.M., Whitton, B.A. \& Brook, A.J. Eds), Cambridge: Cambridge University Press, 2011.

43. GUIRY M.D., GUIRY G.M. AlgaeBase. World-wide electronic publication, National University of Ireland, Galway. 2017. http://www.algaebase.org; (searched on 31 January 2017)

44. SPSS 22.0 IBM Corp. Released. IBM SPSS Statistics for Windows, Version 22.0. Armonk, NY: IBM Corp., 2013.

45. ADDINSOFT, XLSTAT. Data analysis and statistics with MS Excel. Addinsoft, NY, USA, xlstat available at http:// www.xlstat.com/en/home, 2015.

46. BERTILSSON S., AMY B., CAREY C.C., FEY S.B., GROSSART H-P., GRUBISIC L.M., JONES I.D., GEORGIY K., LENNON J.T., ASHLEY S., SMYTH R.L. The under-ice microbiome of seasonally frozen lakes. Limnology and Oceanography, 58 (6), 1998, 2013.

47. TERZHEVIK A., GOLOSOV S., PALSHIN N., MITROKHOV A., ZDOROVENNOV R., ZDOROVENNOVA G., KIRILLIN G., SHIPUNOVA E., ZVEREV I. Some features of the thermal and dissolved oxygen structure in boreal, shallow ice covered Lake Vendyurskoe. Russian Journal of Aquatic Ecology, 43, 617, 2009.

48. SALONEN K., PULKKANEN M., SALMI P., GRIFFITHS R.W. Interannual variability of circulation under spring ice in a boreal lake. Limnology and Oceanography, 59 (6), 2121 2014.

49. YSKYY. Surface Water Quality Management Framework (In Turkish). Official Journal of the publication: Date 15.04.2015, No. 29327, 2015.

50. WETZEL R.G. Limnology: Lake and River Ecosystems. Gulf Professional Publishing, Academic Press, San Diego, 1006, 2001.

51. MANAHAN S.E. Water Chemistry: Green Science and Technology of Naturess Most Renewable Resource. Taylor \& Francis Group, CRC Press, 416, 2011.

52. EC (European Communities). EC of the European Parliament and of the council of 6 September 2006 on the quality of fresh waters needing protection or improvement in order to support fish life. Directive 2006/44, 2006.

53. TOKATLI C. Assessment of Agricultural Pressures on Freshwater Resources of Balkan Arboretum Area (Edirne, Turkey) in A Multistatistical Perspective. $2^{\text {nd }}$ International Conference on Geography, Environment and GIS, 21-23 May 2015, Targoviste, Romania, 2015.

54. D'SOUZA N.A., KAWARASAKI Y., GANTZ J.D., LEE Jr R.E., BEALL B.F.N., SHTARKMAN Y.M., KOCER Z.A., ROGERS S.O., WILDSCHUTTE H., BULLERJAHN G.S., McKAY R.M.L. Diatom assemblages promote ice formation in large lakes. ISME Journal, 7 (8), 1632, 2013.

55. SAROS J.E., ANDERSON N.J. The ecology of the planktonic diatom Cyclotella and its implications for global 
environmental change studies. Biological Reviews, 90 (1), $522,2015$.

56. TWISS M.R., Mc KAY R.M.L., BOURBONNIERE R.A., BULLERJAHN G.S., CARRICK H.J., SMITH R.E.H., WINTER J.G., D'SOUZA N.A., FUREY P.C., LASHAWAY A.R., SAXTON M.A., WILHELM S.W. Diatoms abound in ice covered Lake Erie: Investigation of offshore winter limnology in Lake Erie over the period 2007 to 2010. Journal of Great Lakes Research, 38, 18, 2012.

57. KIILI M., PULKKANEN M., SALONEN K. Distribution and development of under-ice phytoplankton in 90-m deep water column of Lake Paijanne (Finland) during spring convection. Aquatic Ecology, 43 (1), 707, 2009.

58. NÕGES P., NÕGES T., LAAS A. Climate-related changes of phytoplankton seasonality in large shallow Lake Võrtsjärv, Estonia. Aquatic Ecosystem Health \& Management, 13 (1), 154, 2010.

59. Mc KAY R.M.L., BEAL B.F.N., BULLERJAHN G.S., WOITYRA LCDR-W.C. Winter limnology on the Great Lakes: The role of the U.S. Coast Guard. Journal of Great Lakes Research, 37 (1), 207, 2011. 